\title{
Comparison of lake and land tephra records from the 2015 eruption of Calbuco volcano, Chile
}

\author{
Keri McNamara ${ }^{1}$ (D) Alison C. Rust ${ }^{1} \cdot$ Katharine V. Cashman $^{1} \cdot$ Angelo Castruccio $^{2,3} \cdot$ Ana M. Abarzúa $^{4}$
}

Received: 15 July 2018 / Accepted: 8 January 2019 / Published online: 30 January 2019

(C) The Author(s) 2019

\begin{abstract}
Tephra layers in lake sediment cores are regularly used for tephrostratigraphy as isochronous features for dating and recording eruption frequencies. However, their value for determining volcanic eruption size and style may be complicated by processes occurring in the lake that modify the thickness and grain size distributions of the deposit. To assess the reliability of data from lake cores, we compare tephra deposited on land during the 2015 eruption of Calbuco volcano in Chile to records in sediment cores from three lakes of different sizes that are known to have received primary fall deposits. In general, the thickness and granulometry of the deposit in lake cores and nearby terrestrial sections are very similar. As anticipated, however, cores sampled close to (here, within $300 \mathrm{~m}$ of) fluvial inflows were affected by sediment deposition from the lake's catchment; they differed from primary deposits not only in their greater thickness and organic content but also in poor sorting and lack of grading. Cores $850 \mathrm{~m}$ away from the inlet were not affected. We consider our results in the context of the particle settling regime as well as each lake's location, bathymetry and catchment area. We find that the particle settling regime is important in more distal settings where the ash particles are small and particle settling occurs in density plumes rather than as individual particles. We conclude that lake cores can be useful for physical volcanology providing consideration is given to eruption parameters such as particle size and mass flux, as well as lake features such as bathymetry and catchment area.
\end{abstract}

Keywords Lake core $\cdot$ Tephrochronology $\cdot$ Ash deposition $\cdot$ Physical volcanology $\cdot$ Eruption size $\cdot$ Tephra $\cdot$ Calbuco

\section{Introduction}

Lake sediment cores (lake cores) are an invaluable source of information in many spheres of Earth Science such as climatology and volcanology. They can record information about the evolution of water chemistry and aquatic life on time

Editorial responsibility: R. Cioni

Electronic supplementary material The online version of this article (https://doi.org/10.1007/s00445-019-1270-4) contains supplementary material, which is available to authorized users.

Keri McNamara

keri.mcnamara@bristol.ac.uk

School of Earth Sciences, University of Bristol, Bristol, UK

2 Departamento de Geología, Universidad de Chile, Santiago, Chile

3 Centro de Excelencia en Geotermia de los Andes, Santiago, Chile

4 Instituto de Ciencias de la Tierra y TAQUACH, Universidad Austral de Chile, Valdivia, Chile scales of millennia while also preserving deposits from short-lived events such as landslides and volcanic eruptions (Williams et al. 1997; Van Daele et al. 2015). Such events are used to study the associated hazard and as palaeomarkers for correlation and dating (e.g. Horrocks et al. 2005; Lowe et al. 2008; Stern 2008; Lane et al. 2013; Smith et al. 2013). There are, however, many processes that can interfere with a volcanic deposit in a lake and prevent it from recording primary volcanic deposit. Here, we explore these processes as they apply to the 2015 sub-Plinian eruption of Calbuco volcano in Chile.

Lake cores provide a record of the volcanic material deposited during an eruption. This usually comprises pyroclastic material that is released from the ash cloud and settles through the atmosphere onto the lake but can also include deposits from pyroclastic density currents and lahars transported as gravity-driven flows. Lake cores provide important records and samples of distal volcanic deposits, in particular, because lakes are more likely to preserve fine ash that is liable to resuspension and erosion in terrestrial settings (e.g. Lowe 2011; Engwell et al. 2014; Fontijn et al. 2014). In some cases, 
lake cores provide key data to evaluate a volcano's eruptive potential (e.g. Van Daele et al. 2014; Moreno et al. 2015; McNamara et al. 2018) and thus can have considerable implications for hazard management.

In environments where the preservation of tephra on land is particularly poor, lake cores may provide the only record of a volcano's eruptive history. In these scenarios, tephra layers in cores are used in conjunction with material that can be dated (usually organics or carbonates) to establish an eruption chronology, which can be expanded and correlated with land sections or other lake cores (e.g. Davis 1985; Shane et al. 1998; Matthews et al. 2012; Fontijn et al. 2016). Measured thickness and grain size also provide data for constructing isopach and isopleth maps used to estimate eruption size and intensity (e.g. Pyle 1989; Fierstein and Nathenson 1992; Legros 2000; Rhoades et al. 2002; Bonadonna et al. 2005). Furthermore, changes in the grain size and componentry (proportions of clast types) through a deposit can indicate changes in the intensity and style of an eruption with time. These characteristics also provide features for correlating tephra layers found in different locations, particularly in cases where geochemistry is non-diagnostic (McNamara et al. 2018). Application of these methods requires that primary stratigraphic features are preserved in lake cores.

A significant concern in the application of lake cores to physical volcanology is the potential for reworking and emplacement of additional tephra due to lacustrine and fluvial processes. Previous studies of volcanic deposits in lake cores have cited evidence of secondary redistribution such as turbidity currents, which can thin or thicken tephras as sediments slump down the edges of lake basins, or wave action at the higher energy lake edges (Benett 1986; Riggs et al. 2001). Furthermore, a fluvial system delivering tephra from the lake's catchment area can artificially thicken a tephra layer as well as deposit volcanic material in sediments that post-date the eruption (Thompson et al. 1986; Bertrand et al. 2014).

Even without fluvial input or lateral redistribution of volcanic material by currents, settling in the water column can affect the vertical distribution of clasts of different sizes and densities within the deposit. Grading of deposits can be caused by changes to eruption intensity and/or proportions of types of clasts erupted (i.e. primary features) or can be caused by settling processes (i.e. secondary features). Indeed, graded deposits in sea and lake cores have been interpreted to record differing rates of particle settling, where larger particles overtake smaller particles while falling through the water column to produce a normally graded deposit (e.g. Ledbetter and Sparks 1979).

An additional complication is that volcanic material can be highly variable in density; the high vesicle content of pumice may even allow some clasts to float until sufficient pore space is filled with water (Whitham and Sparks 1986). If a portion of the fall deposit comprises pumice that is less dense than water, these pumices may be redistributed (e.g. by wind) on the lake surface while other clasts settle to the lake floor (e.g. Cashman and Fiske 1991; Fiske et al. 2001; Shane et al. 2006; Von Lichtan et al. 2016). Delayed deposition of relatively coarse pumice can also affect the thickness, sorting, grading and componentry of the tephra layer, which complicates interpretations of eruption dynamics.

Finally, clasts do not necessarily settle individually in the water column. Instead, with sufficient rate of tephra deposition onto the sea (for a clast size and density and sufficient water depth), tephra can fall through the water as dense plumes of particles (Carey 1997; Manville and Wilson 2004; Rose and Durant 2009). This occurs when particle fall velocities slow upon reaching the air-water interface, producing higher concentrations near the top of the lake, which may form a gravitationally unstable layer that develops into plumes of particles that descend to the base of the water column. These plumes fall faster than individual-particle settling speeds (Cashman and Fiske 1991; Carey 1997; White et al. 2009; Jacobs et al. 2013, 2015) and are consequently less liable to lateral redistribution by currents (Ninkovich and Shackleton 1975; Manville and Wilson 2004). This type of sedimentation can preserve the primary grain size distribution of tephra; however, it will not preserve grading or fine-scale variations in grain size with stratigraphic height that reflect changes in grain size landing on the water surface with time.

Given the various processes that can interfere with primary tephra deposition in lacustrine environments, an important question is how to recognise when a tephra layer records primary depositional stratigraphy. Also important is identifying the best place to look for pristine tephras within a specific lake. Recent eruptions provide the opportunity to assess the effectiveness of lake core records in a well-constrained environment where contemporaneous deposition of tephra on land and in the lakes can be compared and contrasted (Bertrand et al. 2014).

The 2015 eruption of Calbuco volcano in Chile provides such an opportunity because the sequence of events is well constrained by direct observations and remote sensing, tephra layers were directly measured and sampled on land, and tephra was deposited in lakes of different sizes and locations. Importantly, the accessibility of the proximal fall allowed the tephra deposition to be monitored during and immediately after the eruption. For this reason, the fall deposit is well documented and sampled many kilometres from the vent (e.g. Segura et al. 2015; Castruccio et al. 2016; Romero et al. 2016). As a result, we can compare the deposits in the lake cores to the primary deposit without concern over whether the terrestrial samples have, themselves, been subject to secondary processes. For this study, we cored three proximal lakes. We consider each of the cored tephras in the context of the coring location, proximity to fluvial inputs and the particle settling regime. 


\section{Calbuco volcano}

Calbuco is an active volcano located in the Southern Volcanic Zone (SVZ) of the Chilean Andes. It is one of the most hazardous volcanoes of southern Chile due to the frequency and explosivity of its eruptions, with the towns of Puerto Montt and Puerto Varas located within a $30-\mathrm{km}$ radius of the vent. It is also close to several smaller towns and villages, including the village of Ensenada ( $\sim 14 \mathrm{~km}$ north of the vent).

Activity at the volcano began at $300 \mathrm{ka}$ in the form of andesitic lavas and pyroclastic density currents (PDCs). Holocene activity has produced sub-Plinian and Plinian fall deposits and lava flows and PDCs of predominantly andesitic composition (Lopez-Escobar et al. 1992; Selles and Moreno 2011; Castruccio and Clavero 2015). Activity in the past century has included a range of sub-Plinian and Vulcanian eruptions with the four most recent in 1945, 1961, 1972 and 2015 (Castruccio et al. 2016).

The 2015 eruption of Calbuco began on the 22nd of April with very little precursory activity. Over a 12 -h period, it produced two sub-Plinian phases which occurred $\sim 5.5 \mathrm{~h}$ apart, with a maximum plume height of $25 \mathrm{~km}$ and ash deposited at least $300 \mathrm{~km}$ from the vent. The ash cloud propagated towards the northeast, depositing ash across the Chilean-Argentinian border and causing numerous flight cancellations and delays. The village of Ensenada was particularly affected, with residents evacuated and damage to houses and infrastructure from the volume of tephra deposition.

The second sub-Plinian phase was the most explosive and its products comprise most of the fallout deposits (Van Eaton et al. 2016). The eruption also produced numerous pyroclastic flows that travelled up to $6 \mathrm{~km}$ from the vent, as well as several lahars that followed river channels and caused damage to roads and bridges before entering Llanquihue and Chapo lakes to the north and south of the volcano. The bulk erupted volume was estimated between 0.27 and $0.38 \mathrm{~km}^{3}$ (Castruccio et al. 2016; Romero et al. 2016).

Tephra sampling and analyses of the fall deposit (Segura et al. 2015; Castruccio et al. 2016) identified four units numbered $0-3$ (bottom to top) (Fig. 2), with layer 0 attributed to the first 1.5 -h eruptive phase and layers $1-3$ to the second $6-\mathrm{h}$ phase. Of these units, layer 0 is the thinnest and finest-grained and consists largely of brown scoria. Layer 1 is the coarsest and contains brown to tan scoria. Layer 2 is typically the second-coarsest and encompasses a mix of tan/brown scoria and some denser dark-grey scoria and juvenile lithics. Layer 3 contains dense dark-grey juvenile fragments and grey scoria clasts, which are often coarser grained than those found in layer 2. The easily distinguishable variations in colour, componentry and granulometry with depth in the deposit make this a good eruption for a comparative study of lake and land records of an eruption sequence. In addition, the scoria has a density of $1.3-1.4 \mathrm{~g} / \mathrm{cm}^{3}$ (denser than water;
Castruccio et al. 2016) and so sank immediately upon deposition into the lake.

\section{The lakes}

'Los Lagos' or 'The Lakes' region of Chile comprises the central portion of the SVZ (in which Calbuco is located) and is home to some of the largest lakes in the country. In immediate proximity to Calbuco are Lagos Chapo, Llanquihue and Todos Los Santos (TLS; Fig. 1). The latter is located directly below the 2015 dispersal axis and, consequently, received substantial primary tephra deposition, while the SE sector of Llanquihue lake lies on the northern edge of the fallout area. The region also includes many smaller lakes; some of which are fed by rivers and streams that drain the slopes of Calbuco and nearby Osorno volcanoes. The largest of these small lakes is the elongate Laguna Patas, which is positioned to the east of the volcano, perpendicular to the primary fall axis (Fig. 1). These three lakes comprise our study.

Llanquihue is a piedmont lake with an area of $870 \mathrm{~km}^{2}$ and a maximum depth of $317 \mathrm{~m}$, making it the second largest lake in Chile (Geller 1992; Soto 2002). Llanquihue and neighbouring Todos Los Santos lie in the same large quaternary glacial depression, which has been partially filled by volcanic products from Calbuco and Osorno volcanoes to create the two distinct lakes (Herschy 2012). Llanquihue lies $12 \mathrm{~km}$ to the north and northeast of Calbuco and received most tephra deposition in its SE tip. It has several fluvial inflows, with the main three comprising Rio Pescado, Rio Blanco and Rio Tepu; all of which are sourced on or near the flanks of Calbuco and flow into the southern shore of the lake (Campos et al. 1988; Arismendi et al. 2011; Fig. 1). The lake's primary fluvial outflow is the Maullín river which flows from the town of Llanquihue in the southwest of the lake.

Todos Los Santos (TLS) is a monomictic lake positioned approximately $28 \mathrm{~km}$ northeast of Calbuco in the Vicente Perez Rosales National Park, directly beneath the 2015 ash dispersion axis (Fig. 1). The lake has a surface area of $178.5 \mathrm{~km}^{2}$ and a maximum depth of $337 \mathrm{~m}$ (Herschy 2012). It has three major fluvial inflows (rivers Blanco, Pichi-Blanco and Negro); all of which enter the eastern end of the lake. The most easterly $5-\mathrm{km}$ basin of the lake has a maximum depth of $50 \mathrm{~m}$ because of sediment deposition from the rivers. Its western basin is much deeper, reaching $330 \mathrm{~m}$ in some places. The major lake outflow is located at the most westerly extent of the lake and constitutes the source of the Petrohué river (Fig. 1).

Laguna Patas is a small lake to the east of Calbuco with a surface area of $0.6 \mathrm{~km}^{2}$. It is fed from a small river (estero El Caballo) entering in the southeast end of the lake whose catchment comprises part of the easterly flank of Calbuco but is nearly dry during the summer season (Bretón et al. 2006). The lake feeds the Rio de los Patos, a larger tributary of the main Petrohué River (Fig. 1). To our knowledge, no bathymetric 


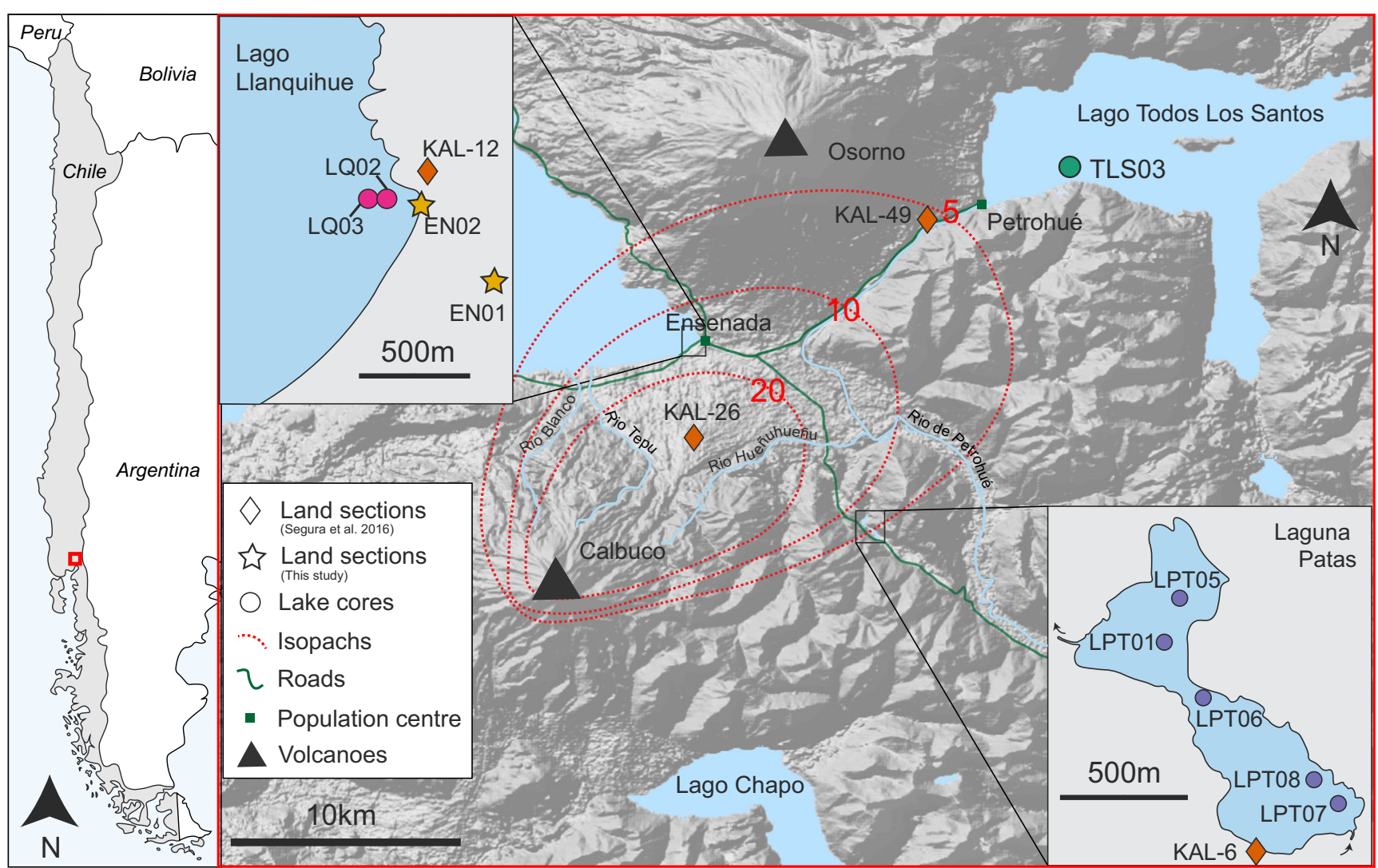

Fig. 1 Map of Calbuco volcano and the 2015 fallout deposit, including all locations of sampling and isopach map as determined by Castruccio et al. (2016)

information exists for the lake; however, our measurements with an echo-sounder during coring suggest typical depths between 10 and $30 \mathrm{~m}$.

\section{Methods}

All cores were obtained during fieldwork in March 2017 using a Uwitec gravity corer and $60 \mathrm{~mm}$ sampling tubes. Equipment limitations meant the maximum water depth through which we could core was $40 \mathrm{~m}$, so all cores were taken within $300 \mathrm{~m}$ of the lake shore, where the water depth varied from 8.5 to $40 \mathrm{~m}$.

All cores were measured, photographed and described immediately after coring and then subsampled on return from the field. The core was episodically removed by sliding the outer casing down to expose sediment, which was then sampled. We aimed to sample the core every $2 \mathrm{~cm}$; however, due to the coarse nature of the sediments, it was difficult to control the removal of the core from its casing and so subsampling was sometimes at inconsistent intervals. A summary of the cores and sub-samples can be found in Table 1 .

Selective terrestrial sections are also included in this study (Table 1). These comprise tephra sampled at the time of coring as well as sections sampled by Segura et al. (2015) and
Castruccio et al. (2016) immediately after the eruption. We compare sections close to the cored lakes to allow a direct comparison of both granulometry and componentry between the terrestrial tephra deposit and the lacustrine material. In addition, we compare grain size and thickness data of the lake core samples with those of deposits sampled at intervals along the ash dispersion axis (Castruccio et al. 2016; Fig. 1). Thickness data from these localities were used to draw isopachs by Castruccio et al. (2016), which are also shown on Fig. 1.

Grain size data were gathered for each subsample in each core and deposit. The samples were oven-dried, sieved from 5 to $3 \varphi(32 \mathrm{~mm}$ to $125 \mu \mathrm{m})$ at $1 \varphi$ intervals and weighed. Samples with macroscopic organic content (leaves and twigs; Table 1) were subsequently resaturated in water, and all floating organic material was manually removed before the remaining sample was re-dried. In order to determine the total grainsize for each core, the weights of the subsample were summed for each grain size fraction and combined into a distribution. All grain size data can be found in Supplementary Material S3. Componentry data were analysed for the $-2 \phi$ fraction by sorting individual grains into one of three categories: (1) dense, grey fragments, (2) brown scoria and (3) beige to white pumice. Grain size sorting $\left(\sigma_{\phi}\right)$ was calculated using the parameters of Inman (1952), where $\sigma_{\phi}$ is half the difference 
Table 1 Summary of cores and subsampled for each of the lakes

\begin{tabular}{|c|c|c|c|c|c|c|c|c|c|c|c|}
\hline \multirow[t]{2}{*}{ Sample } & \multicolumn{2}{|l|}{ Location } & \multirow[t]{2}{*}{ Thickness (cm) } & \multicolumn{7}{|c|}{ Subsample thickness (cm) } & \multirow[t]{2}{*}{ Macoscopic organics removed } \\
\hline & $\mathrm{S}$ & $\mathrm{W}$ & & A & $\mathrm{B}$ & $\mathrm{C}$ & $\mathrm{D}$ & $\mathrm{E}$ & $\mathrm{F}$ & $\mathrm{G}$ & \\
\hline \multicolumn{12}{|c|}{ Land sections } \\
\hline EN02 & 4113.418 & 07231.820 & 13 & 5 & 8 & - & - & - & - & - & \\
\hline KAL-49 & 4108.924 & 07225.810 & 6 & - & - & - & - & - & - & - & \\
\hline KAL-06 & 4118.408 & 07227.246 & 5 & 1 & 2 & 2 & 1 & - & - & - & \\
\hline KAL-12 & 4112.194 & 07232.251 & 15 & - & - & - & - & - & - & - & \\
\hline \multicolumn{12}{|c|}{ Lake Llanquihue } \\
\hline LQ02 & 4112.291 & 07232.486 & 13 & 1 & 5 & 2 & 3 & 2 & - & - & \\
\hline LQ03 & 4112.293 & 07232.534 & 13 & 3.5 & 3.8 & 2 & 3 & - & - & - & \\
\hline \multicolumn{12}{|c|}{ Lake Laguna Patas } \\
\hline LPT01 & 4117.726 & 07227.480 & 8 & 1 & 1 & 1 & 1 & 1.5 & 1 & 1 & $\mathrm{Y}$ \\
\hline LPT05 & 4117.756 & 07227.426 & 8 & 2 & 2 & 2 & 2 & 2 & - & - & $\mathrm{Y}$ \\
\hline LPT06 & 4118.033 & 07227.362 & 7 & 1 & 1 & 1 & 1 & 1.5 & 1 & 1 & $\mathrm{Y}$ \\
\hline LPT07 & 4118.296 & 07226.964 & 12 & 2 & 2.5 & 2 & 2 & 2 & 2 & - & Y \\
\hline LPT08 & 4118.245 & 07227.043 & 10 & 2 & 2 & 2 & 2 & 2 & - & - & $\mathrm{Y}$ \\
\hline \multicolumn{12}{|c|}{ Lake Todos Los Santos } \\
\hline TLS03 & 4107.615 & 07221.235 & 5 & 1 & 1 & 1 & 1 & 1 & 1 & - & \\
\hline
\end{tabular}

between the 84 th percentile and the 16 th percentile of the grain size distribution.

Backscatter electron (BSE) scanning electron microscope (SEM) images were obtained for the uppermost and two lowermost subsamples in three of the Laguna Patas cores. In each case, the $2 \varphi, 3 \varphi$ and $>3 \varphi$ grain size fractions were imaged. Particles were mounted in epoxy and polished to expose particle interiors. Polished mounts were then carbon-coated before imaging with a Hitachi S-3500N SEM at the University of Bristol. For each grain size fraction, a $\sim 15$-image mosaic was obtained and then combined using FIJI grid stitching software (Schindelin et al. 2012). Each image had a $1024 \times$ 769 pixel resolution and was taken at a working distance of $20 \mathrm{~mm}$ and an accelerating voltage of $15 \mathrm{kV}$ or $20 \mathrm{kV}$.

To better understand the secondary input of ash into the lakes, we delineated the drainage basins for each lake using the drainage analysis feature of the spatial analyst toolbox in ArcGIS, which models water accumulation based on topography and computes boundaries between drainage areas. The data were calculated using a 30-m DEM from Shuttle Radar Topographic Mission (STRM) data. See Supplementary Material S1 for detailed methods.

\section{Deposit properties}

Several land sections (described below) were selected for comparison based on their proximity to the cores or position relative to the ash dispersal axis. In addition, eight cores were obtained across the three lakes: Lago Llanquihue (two cores), Lago Todos Los Santos (one core) and Laguna Patas (five cores) (Fig. 1). The maximum sediment depth cored was $50 \mathrm{~cm}$, although most cores were $\sim 30 \mathrm{~cm}$ deep (Fig. 1). Core numbers (Table 1) reflect the order in which they were collected at a given lake; gaps in the numbering correspond to unsuccessful attempts to retrieve core (e.g. the tube broke or was empty).

\section{Tephra on land}

The majority of tephra in this study was sampled immediately after the eruption (Segura et al. 2015; Castruccio et al. 2016). The only exception is a sample from a shallow pit on the shore near Ensenada (location EN02; Fig. 1), which was dug at the time of coring to compare to the cores sampled $200 \mathrm{~m}$ to the WNW in Lago Llanquihue. The sample is $13 \mathrm{~cm}$ thick, and all four units determined by Castruccio et al. (2016) are identifiable (Fig. 2). We subsampled the top and bottom half of the tephra deposit. The deposit contains darker pyroclasts in the upper $\sim 4 \mathrm{~cm}$; the lower $\sim 4 \mathrm{~cm}$ contains large sub-angular tan pyroclasts. The upper $6 \mathrm{~cm}$ of the deposit is finer-grained $(\mathrm{Md}=-0.6 \varphi)$ than the lower $5 \mathrm{~cm}$, which is considerably coarser $(\mathrm{Md}=-1.3 \varphi)$ (Fig. 2).

Tephra sampled immediately after the eruption in nearby Ensenada village (KAL-12) is $\sim 400$ m closer to the vent than EN02 and was recorded as $15 \mathrm{~cm}$ thick (Segura et al. 2015; Castruccio et al. 2016). A sample collected at the same time close to the village of Petrohué, south west of Todos Los 
Santos ( $\sim 24 \mathrm{~km}$ from the vent), is used to compare with the core sampled from Todos Los Santos. The deposit was recorded as $6 \mathrm{~cm}$ thick immediately after deposition (site KAL-49; Fig. 1), with the lower $3 \mathrm{~cm}$ slightly coarser than the upper $3 \mathrm{~cm}$ (Fig. 3). The grain size variations are less obvious than in the more proximal deposits.

Ash on the shore of Laguna Patas (KAL-6) was recorded as $5 \mathrm{~cm}$ thick immediately after the eruption (Segura et al. 2015; Castruccio et al. 2016) and can be compared to the cores taken from the Laguna. However, samples for granulometry were not taken from this site and so grain size cannot be compared directly.

For reference, we also include data from tephra sampled very close to the dispersal axis, $\sim 5.5 \mathrm{~km}$ from the vent (sample KAL-26; Fig. 1). The deposit, also sampled immediately after the eruption, is $30 \mathrm{~cm}$ thick and, as seen in EN02, is coarser in the lower half, with the basal layer (layer 0 ) slightly finer $(\mathrm{Md}=$ $-1.6 \varphi)$ than the thicker layer 1 above it $(\mathrm{Md}=-2 \varphi$; Fig. 3$)$.

\section{Llanquihue cores}

The two cores taken from Lago Llanquihue (LQ02 and LQ03) were sampled $50 \mathrm{~m}$ apart and $\sim 200 \mathrm{~m}$ from the shore and $~$ $15 \mathrm{~km}$ from the volcano (Figs. 1 and 2). The tephra has a sharp contact with lake sediment below, although this was not always apparent until subsampling as coring caused the sediment to smear along the edge of the core tube. Tephra deposits in both cores had a thicknesses of $\sim 12 \mathrm{~cm}$ (Fig. 2), and there was a $\sim 1$-cm layer of lake sediment on top of the tephra. The grain size and colour varied visibly in the deposit: the upper half of the layer was generally finer and darker grey in colour, while the lower half was coarser and comprised a band of tancoloured 5-10 mm-sized scoria above a finer layer of darker brown scoria.

The grain size distributions varied with depth $(\mathrm{z})$ in both cores. Both cores were subsampled: LQ02 four times (A-D; top to bottom) and LQ03 five times (A-E; top to bottom) (Table 1). Of the four LQ02 subsamples, the two lowest are coarser with median grain size $(\mathrm{Md})=-0.8 \varphi(\mathrm{LQ} 02 \mathrm{~A}$ and LQ02B), while in the upper two, $\mathrm{Md}=-0.6 \varphi$ (LQ02C and LQ02D) (Figs. 2 and 3). The LQ03 tephra layer includes five subsamples, with the upper three (LQ03A, LQ03B and LQ03C) more fine-grained than the lower two (LQ03D and LQ03E), mirroring the overall grain size trends of the LQ02 deposit (Fig. 3). There is more variation in the Md in LQ03 (each subsample has a slightly different $\mathrm{Md}$ ), as expected given the different sampling intervals.

\section{Todos Los Santos cores}

Coring was attempted only in the deeper, westerly basin of TLS where we retrieved one core (TLS03). This core was taken $\sim 31 \mathrm{~km}$ from the volcanic vent. It was the longest core obtained and contained at least two separate tephra deposits. The uppermost tephra (the 2015 tephra) is $5 \mathrm{~cm}$ thick and is clearly distinct from surrounding lake sediment in grain size, sorting and colour. The tephra shares a clear boundary with the lake sediment below and above. The grain size of the deposit does not change with depth, and $\mathrm{Md}=\sim 1.4 \varphi$ for all subsamples (Fig. 4).

\section{Laguna Patas cores}

Five cores were taken from this lake, which lies $\sim 13 \mathrm{~km}$ from the vent, at intervals along the lake axis: LPT07, LPT08, LPT06, LPT01 and LPT05 (in order of increasing distances from the river entry; Fig. 1). We separate the core samples into two groups: (1) the thinner tephras in cores LPT06, LPT01 and LPT05 which thicken to the northwest $(7 \mathrm{~cm}, 8 \mathrm{~cm}$ and $8 \mathrm{~cm}$, respectively) and (2) the thicker tephras (LPT07 and LPT08) which thin towards to northwest, away from the river source (12 $\mathrm{cm}$ and $10 \mathrm{~cm}$, respectively).

The three thinner tephra layers have distinct boundaries with lake sediment above and below and contain very little lake sediment amongst the ash. Each core showed systematic grain size variation across the subsamples of the tephra layer, with the upper $2 \mathrm{~cm}$ finer than the lower $6 \mathrm{~cm}$. In all three cores, subsamples from the middle $(\mathrm{z}=4-6 \mathrm{~cm})$ are the coarsest, with $\mathrm{Md}=\sim 0.6 \varphi$, while those from the bottommost $3 \mathrm{~cm}$ are finer $(\mathrm{Md}=\sim-0.5)$. LPT06 displays slightly more heterogeneity in grain size than the other two cores and has a finergrained lower $3 \mathrm{~cm}(\mathrm{Md}=0.4)$ (Fig. 3).

The thicker tephras closer to the river mouth comprise ash interspersed with lake sediment and organic material, including leaves and twigs, and have less distinct boundaries with the surrounding lake material. They also differ from the thinner cores in their grain size trends: they are generally finergrained and show inconsistent variation with depth. LPT07 contains a lens of very fine material at $\mathrm{z}=4 \mathrm{~cm}$, while LPT08 is much finer-grained in the upper $2 \mathrm{~cm}$ than any of the other cores (Fig. 3). While the overall grain size of both cores is on average smaller, both contain large $(\sim 2 \mathrm{~cm})$ lithic fragments.

\section{Comparison of lake and land tephras}

The primary purpose of this study is to compare the tephra that has settled directly into lakes to the tephra that settled on land. We do this by comparing basic physical observations of the tephra deposits from both preservation environments. Grain size and thickness are regularly used to estimate eruption size and intensity (e.g. Pyle 1989; Burden et al. 2011; Johnston et al. 2012; Castruccio et al. 2016; Romero et al. 2016); for this reason, we compare the thickness and granulometry of each of the lake core deposits to nearby ash on land. Also 
Fig. 2 Grain size data of different sub samples in the terrestrial section on the shore of Llanquihue (EN02) and lake core (LQ02) sampled $\sim 200 \mathrm{~m}$ from the shore. Both show coarser sediment in the lower half of the deposit. The distinctive eruptive units as defined by Castruccio et al. (2016) are highlighted in white. The coloured lines and arrows correspond to each subsample (lettered A-E). The line dash and colour are the same for the relevant grain size distribution of the subsample
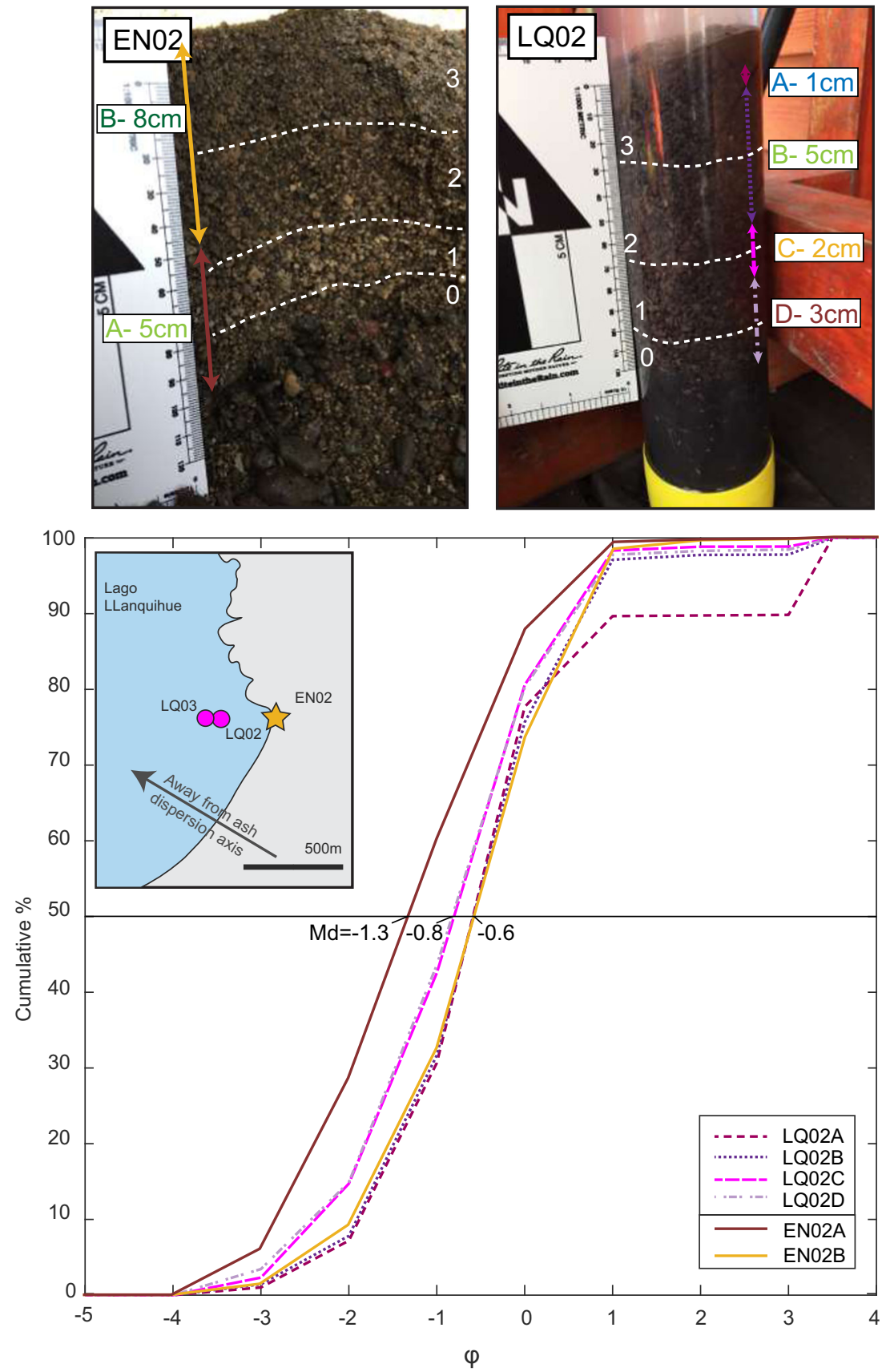

important is the proximity of each lake site to fluvial inflows as well as to the lake size and catchment. We also consider the features of the deposit in relation to the eruption properties and resultant particle settling regime.

All 2015 tephras used in this study were sampled from within an area affected by primary deposition from the 2015 eruptive plume. The three lakes that were cored-Lago Llanquihue, Lago Todos Los Santos and Laguna Patas-are of varying sizes and types. Laguna Patas is the closest to the volcanic vent $(\sim 13 \mathrm{~km})$, although it did not receive the thickest tephra of the lakes cored because of its position southeast of the dispersal axis, which is set by the wind direction during the eruption. The thickest tephra deposition was recorded in cores from Lago Llanquihue, which is $\sim 15 \mathrm{~km}$ from the vent and close to the dispersal axis. The thinnest 2015 tephra layer was sampled in Todos Los Santos, close to the main ash dispersal axis but $\sim 31 \mathrm{~km}$ from the vent (Fig. 1).

\section{Comparisons of deposit features}

The thicknesses of the 2015 tephra in both cores taken from Lago Llanquihue (LQ02 and LQ03) are within the range 


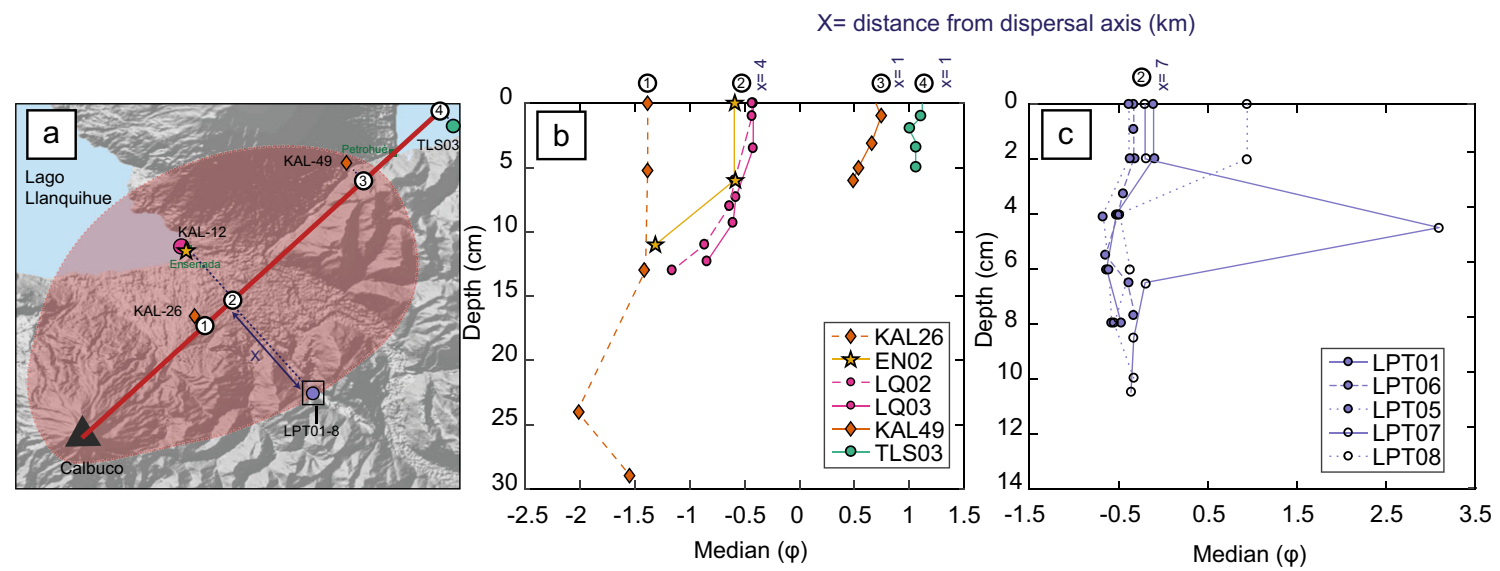

Fig. 3 Median grain size (Md $\phi)$ with depth for all lake cores and land sections. Generally, all deposits show reverse grading. a $\mathrm{Md} \phi$ with depth for lake cores TLS03, LQ03 and LQ03 and land sections KAL49 and

expected based on the isopach map constructed from primary land deposits by Castruccio et al. (2016). The cores also show grain size and colour changes with depth comparable to the section sampled on land close to the lake edge (EN02; Figs. 2 and 3; Supplementary Material S3). Colour changes are reflected in the componentry data which indicate that the proportion of beige to white pumice in the $2 \phi$ fraction increases in the middle and lower subsamples in both the LQ02 core and the EN02 land sample. In both cores, the lower half of the deposit is coarser than the upper half, and the same four units were identifiable from grainsize and colour (Fig. 2). Sorting, as determined using sorting parameters in Inman (1952), in both the land and lake core is also comparable, with $\sigma_{\phi} \sim 1$ in

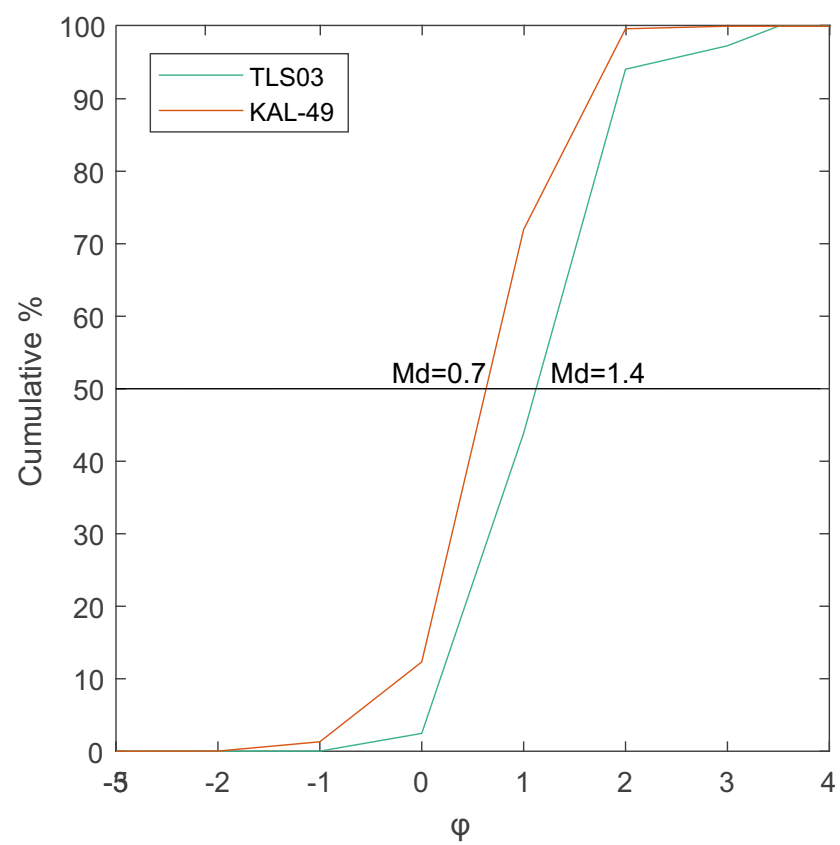

Fig. 4 Grain size of Todos Los Santos core (TLS03) compared to the nearby land section (KAL-49)
EN02. b Md $\phi$ with depth for all Laguna Patas cores. Note that Laguna Patas is off axis from the main dispersal axis (see Fig. 1)

all subsections of both land and lake deposits (Supplementary Material S3). However, the bottom subsection is less well sorted due to the possible inclusion of lake sediment as well as sampling combining finer grains from the first layer 0 with a portion of the coarser deposits from layer 1. Generally, however, the lake core is slightly finer-grained in the lower two subunits than in the lower half of the land section. In LQ02, for instance, $\mathrm{Md}=-0.8 \varphi$ in the lower two subsamples, while $\mathrm{Md}=-1.3 \varphi$ in the lower half of EN02 (Fig. 2). We interpret this to reflect the distance of the cores from the primary dispersion axis, which is consistent with the layer in the cores also being slightly thinner than in the land section EN02. Additionally, it is not strictly accurate to compare the bottommost subsamples from the lake cores and the land sections, as they represent a different proportion of the overall deposit.

As seen in Lago Llanquihue, the core from Todos Los Santos (TLS03) contains 2015 tephra with a thickness consistent with the isopach contours based on deposits on land. Although the closest tephra section on land (KAL-49; Segura et al. 2015) is coarser than the lake core, it is $\sim 6 \mathrm{~km}$ closer to the volcano (Figs. 3 and 4). Additionally, the normal grading observed in all the land sections is not as apparent in TLS03 (Fig. 3), consistent with the observation that even on land, the four units become less distinctive with distance from the volcano (Castruccio et al. 2016).

In Laguna Patas, the smallest of the lakes sampled (Fig. 1), the characteristics of the tephra varied with the positions of the cores relative to the primary dispersal axis and the lake's fluvial inflow. In the three cores closest to the volcano (LPT01 to LPT05 and LPT06), the tephra layer thins with increasing distance from the dispersal axis, consistent with the wellconstrained primary deposit on land. The grain size also changes systematically across these three cores, although unlike the land sections and cores from other lakes, the bottom half of the deposit is not coarser than the top (Fig. 3a). In fact, after the samples were dried, we identified a contribution of 
lake sediment in the bottom 2-4 subsamples in all three cores. To investigate the impact of this mud on the grain size distribution, we imaged the finest three grain size fractions by SEM. In each case, we observed aggregates comprising mostly diatomite and some organic material. The proportions of volcanic and non-volcanic particles were quantified by point counting, and the non-volcanic portion was removed from the grain size fraction to create a primary grain size distribution (Fig. 5). The revised (purely volcanic) grain size indicates normally graded deposits, consistent with normal grading displayed in land sections and in Llanquihue cores (Fig. 3).

The tephra layers in the other two cores (LPT07 and LPT08) have thicknesses and grain sizes that contrast with the other three cores; we attribute this difference to their proximity to the lake's fluvial inlet (Estero El Caballo; Fig. 6). Specifically, the tephra layers were considerably thicker and finer-grained than their co-lake counterparts (Figs. 3 and 6) and contained lenses of mud and organic material amongst the tephra (Fig. 3). This is reflected in the $\sigma_{\phi}$, which varies from 1.7 to 2.9 across the subsections of LPT07, considerably greater than the unaffected core LPT01, where $\sigma_{\phi}$ ranges between 1.1 and 1.7. Componentry indicates higher proportion dense fragments distributed throughout the deposit, unlike the other Laguna Patas cores, which contained more dense fragments towards the top.

We interpret these cores to contain material washed in from the lake catchment, which explains the overthickening, grain size trends and changes in componentry (Figs. 4 and 6; Supplementary Material S3). As no portion of the overthickened cores matches the stratigraphy in the cores away from the inlet (LPT01, LPT05 and LPT06), it appears that volcanic material from the river was deposited in the lake during the eruption and disturbed the primary fall material as it washed in. It should be noted that these overthickened deposits comprise mostly tephra despite the included organic matter.

In summary, most of the deposits in the lake cores preserved grain size and thickness information comparable to land sections and are interpreted to represent the primary deposits. Indeed, in all cases (with the exception of the fluvially thickened deposits), the measured thicknesses of both lake and land deposits were within the measuring error determined by Engwell et al. (2014) for their distance from the volcano. Moreover, the cores were sampled only $\sim 100 \mathrm{~m}$ from the lake edge, which indicates that, despite their location, the effect of wave action on sedimentation is negligible.

\section{Fluvial inflows and drainage basins}

We also investigated the effect of different drainage basins on the tephra deposits in lakes using drainage basin analysis in ArgGIS (Fig. 7). This is important because it has been shown that in some settings, deposition of volcanic particles carried into a lake by rivers may interfere with primary deposition and
Fig. 5 Median grain size with depth for the three non-fluvially thickened lake cores from Laguna Patas. a Without lake sediment removed; SEM images show proportions of lake sediments in the $3 \phi$ grain size fraction. $\mathbf{b}$ With lake sediment removed
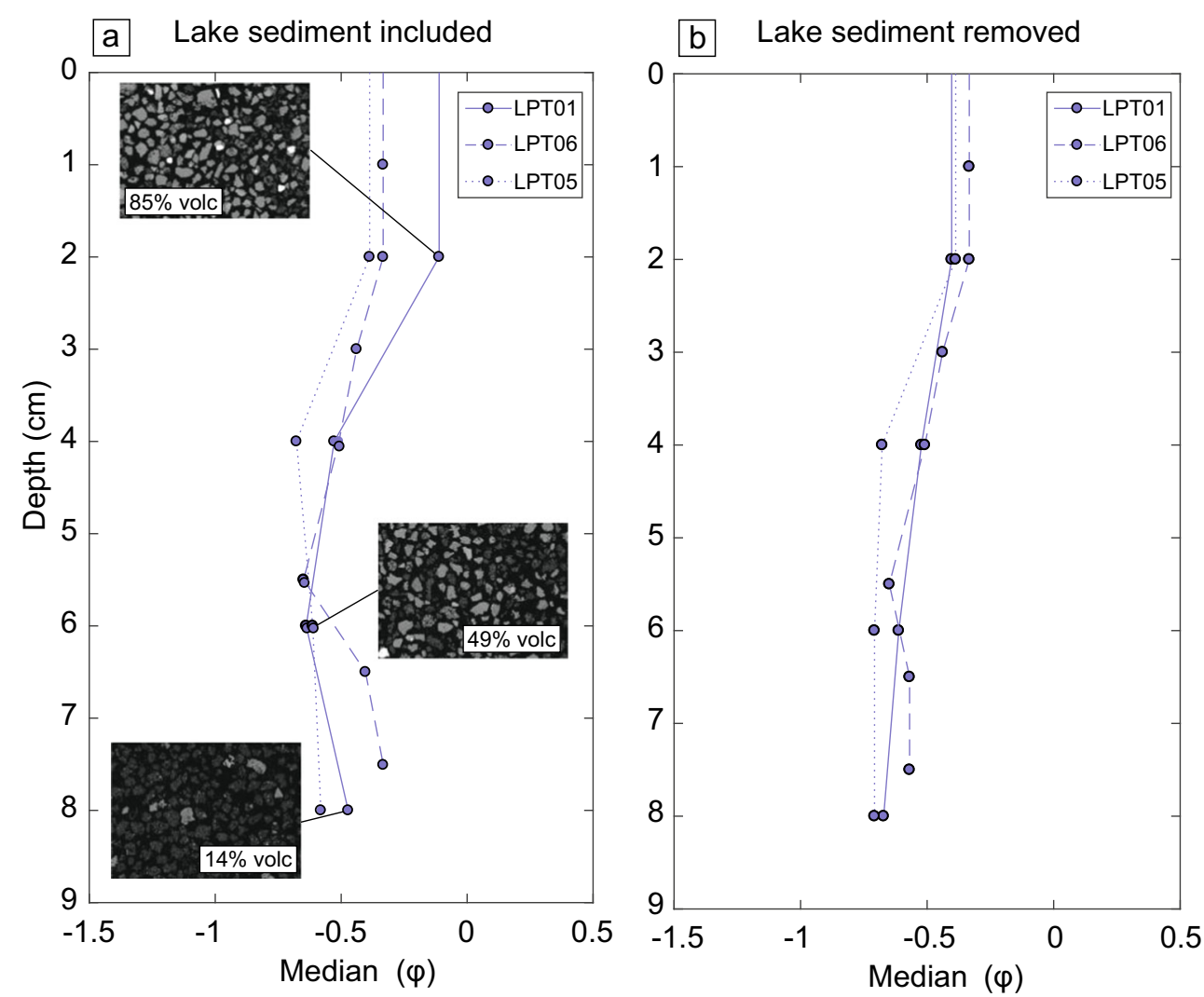


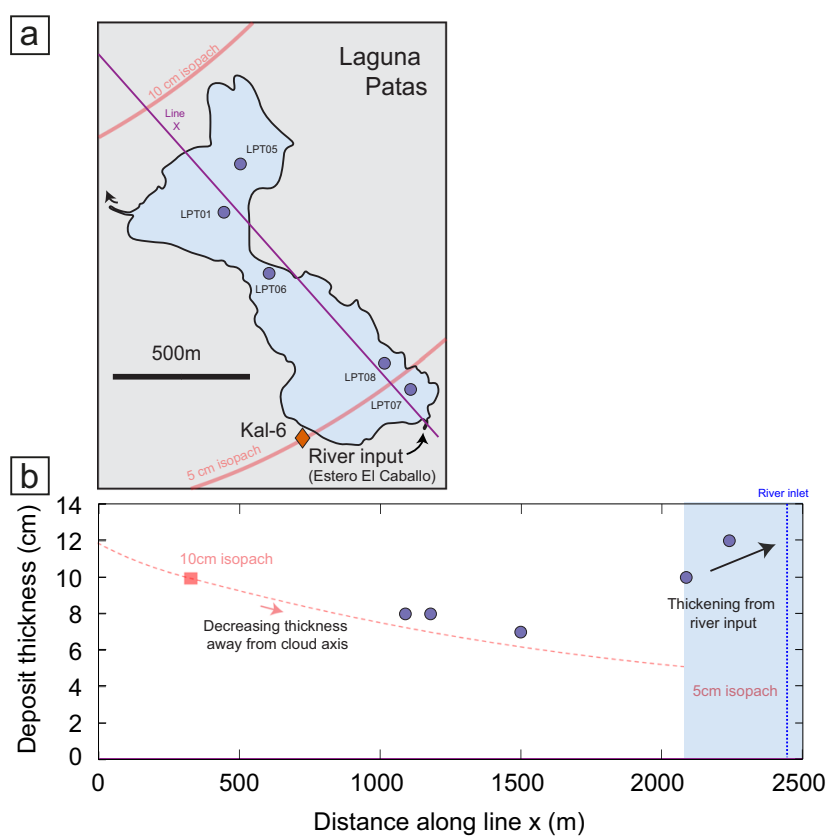

Fig. 6 Thickness of the tephra deposit in Laguna Patas lake cores. a Purple line marks a transect approximately perpendicular to the ash cloud dispersal axis. b The position of the cores along the purple line (determined by orthogonal projection of the points onto the line). Red squares indicate the point at which the isopach contours cross the transect and red dashed line indicates an interpolation between the points at which the $20,15,10,5$ and $1 \mathrm{~cm}$ isopachs cross the transect (the curve is only displayed for the range of line $\mathrm{X}$ shown on map however). Blue shaded area indicates area affected by thickening from the fluvial inflow

cause discrepancies between land and lake records (Bertrand et al. 2014). For instance, immediately north of Lago Llanquihue is Lago Puyehue which, after the 2011-2012 eruption of Cordón Caulle, was found to contain millimetrethick tephra deposits across most of the lake (which has a surface area of $164 \mathrm{~km}^{2}$ ) that were not consistent in thickness or grainsize with nearby primary land deposits (Bertrand et al. 2014). Here, volcanic material was apparently washed in from the fluvial system (primarily the river Golgol) that was fed from a catchment area directly under the ash dispersal axis.

Interestingly, the fluvial input of the Calbuco lakes appears much less important. It is not surprising that the core in Todos Los Santos (TLS03) has not been affected as the lake's catchment area does not lie directly under the area of substantial primary ash deposition and the core is $10 \mathrm{~km}$ from the nearest inlet. However, the catchments of the two other lakes do contain substantial fallout from Calbuco and the cores were all collected close to river inlets.

In Laguna Patas, only cores within $300 \mathrm{~m}$ of the inlet have been affected by fluvial inputs (Fig. 6); a core $850 \mathrm{~m}$ from the inlet is consistent with land records and appears primary. Our drainage basin analysis indicates that Laguna Patas is fed from a catchment that comprises the eastern flank of Calbuco (Fig. 7). This may explain the presence of large lithics amongst fine sediment, as well as the poor sorting and grainsize trends. There are no published data on Estero El Caballo, the river supplying Laguna Patas, but Google Earth images indicate that the river is $\sim 2.5 \mathrm{~km}$ long and so is expected to have carried only a small volume of tephra.

There is the lack of secondary tephra deposition in cores of Lago Llanquihue, which is fed by larger river systems and so is more vulnerable to extensive secondary redistribution of sediment. The cores (LQ02 and LQ03) were taken only $5 \mathrm{~km}$ from the inlet of the Tepu River, which fed several lahars during the eruption. Lago Llanquihue is almost five times the size of Lago Puyehue, but any Calbuco ash entering via the river systems does not seem to have been distributed to the same extent as the ash transported into Puyehue after the Cordón Caulle eruption. The catchment areas for both lakes (Llanquihue and Puyehue) are under the primary dispersal axes for the Calbuco and Cordón Caulle eruptions, respectively (Fig. 7; Bertrand et al. 2014), and so will have received ash. However, the Golgol river is $55 \mathrm{~km}$ long and has a discharge rate of 73-274 $\mathrm{m}^{3} \mathrm{~s}^{-1}$ (Campos et al. 1988; Arismendi et al. 2011). In contrast, the Tepu river is $18 \mathrm{~km}$ long with an average monthly discharge of 2-5 $\mathrm{m}^{3} \mathrm{~s}^{-1}$ (Campos 1986) and a drainage area of $32 \mathrm{~km}^{2}$ (only $2 \%$ of the whole Lago Llanquihue drainage basin; Arismendi et al. 2011). In addition, Lago Puyehue has a catchment area of $1510 \mathrm{~km}^{2}$, comparable to that of Llanquihue $\left(1605 \mathrm{~km}^{2}\right)$ despite the area of the lake itself being five times smaller. Therefore, we infer that the thick layer of secondary tephra deposited in Puyehue was a consequence of a longer fluvial network, a higher discharge rate and a large catchment area in comparison to Llanquihue. It is also perhaps important that the drainage boundary closest to the Llanquihue cores (in the village of Ensenada) is the boundary between Calbuco and Osorno drainage basins (Fig. 7). It is possible that the area close to the bay in Ensenada did not receive runoff from Calbuco, which would have limited the effects of secondary deposition.

\section{Particle settling regime}

Volcanic particles settle in water (1) as individual particles or (2) in plumes as part of a particle-laden vertical density current (e.g. Ledbetter and Sparks 1979; Wiesner et al. 1995; Carey 1997; Carey and Schneider 2011). While the settling regimes of volcanic particles deposited in oceans are fairly well understood (e.g. Wiesner et al. 1995; Carey 1997; Manville and Wilson 2004; Shane et al. 2006), they have not been considered in detail for a lacustrine setting where water depths are shallower. Our results show that the lake cores (at least in the proximal lakes Lago Llanquihue and Laguna Patas) are representative of the deposits on land, so we infer that the particles settled individually, rather than by collective settling in plumes. 
Fig. 7 Drainage basins calculated using hydrology toolbox in ArcGIS. Area of $5 \mathrm{~cm}$ isopach defined by Castruccio et al. (2016) shown in red
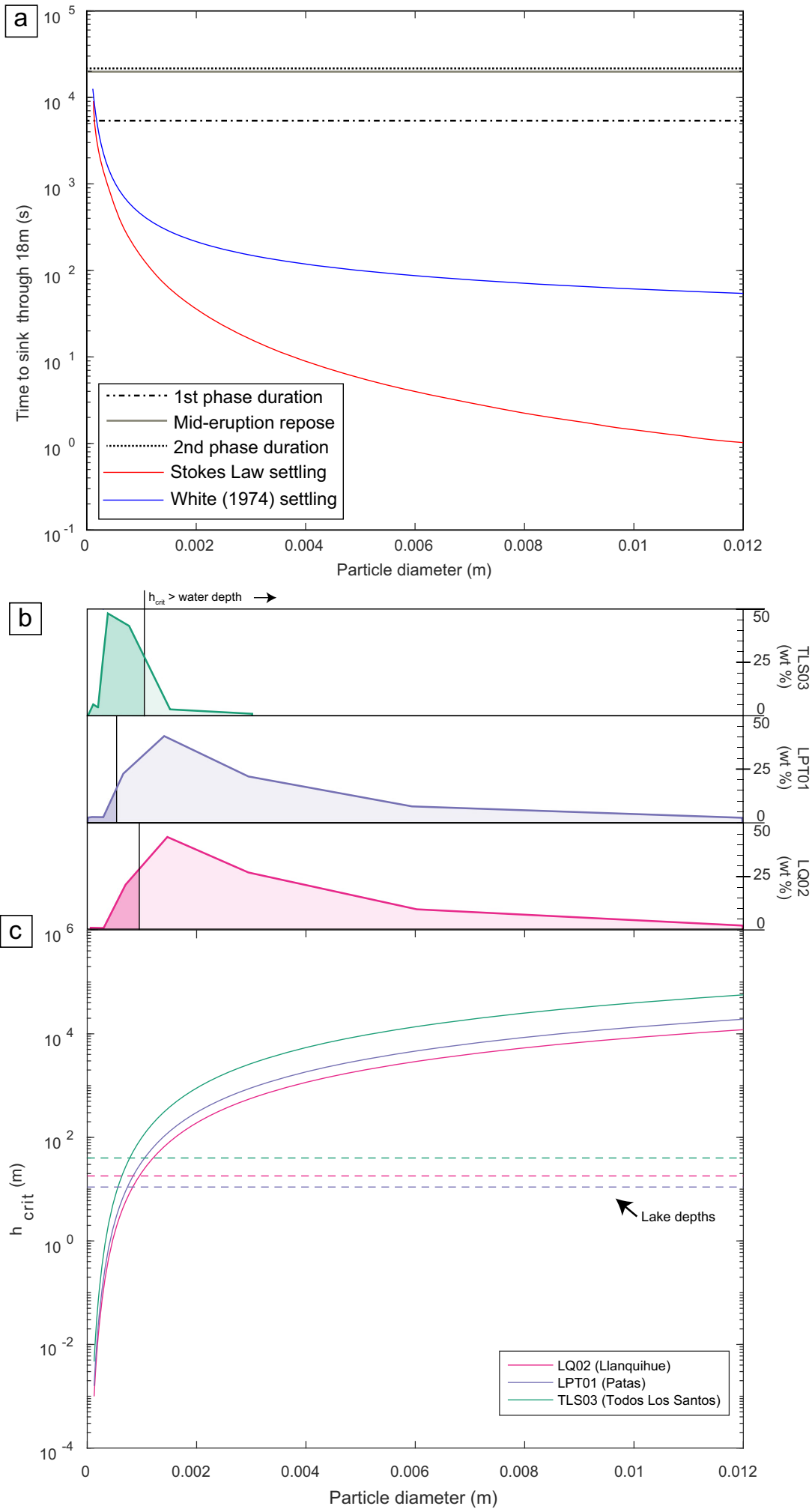

To quantify the timescales of individual particle settling in the lakes, we calculated fall velocities for the range of particle sizes in the cores. Assuming spheres and a particle density of $1350 \mathrm{kgm}^{-3}$ (Castruccio et al. 2016), we calculated settling velocities using the formulation of White (1974), which is appropriate for the full range of Reynolds numbers $(\mathrm{Re})$ from viscous-dominated drag $(\operatorname{Re}<<1)$ for smallest particles to inertial-dominated drag $(\mathrm{Re}>>1)$ for largest particles. For 
each particle size, we started by establishing the velocity according to Stokes law $(\operatorname{Re}<<1)$ and calculated Re based on this velocity. We then determined the Re-dependent velocity according to White (1974) and iteratively recalculated velocity (with updated Re) until the values converged. The effect of the drag on settling times (=depth divided by velocity) for the range of particle sizes in the cores is shown in Fig. 8a.

In order for the individual particle settling regime to transition into collective settling, the relatively particle-rich (and hence dense) layer that accumulates in the upper water column must destabilise. As more particles enter the water, this particle-bearing layer thickens with time until it reaches a critical thickness $\left(h_{\text {crit }}\right)$. At this thickness, the timescale for an individual particle to fall through the layer $\left(\tau_{\text {ind }}\right)$ equals the timescale for dense plumes of particles to develop by Rayleigh-Taylor instabilities ( $\tau_{\text {coll }}$ ) (Marsh 1988; Carazzo and Jellinek 2012; Jacobs et al. 2015). In order for this collective settling to occur in a lacustrine setting, the lake must be deeper than $h_{\text {crit. }}$.

To investigate whether the lakes are sufficiently deep for the Calbuco tephra to settle collectively, $h_{\text {crit }}$ was calculated for the range of particles sizes in the cores. We use the derivation for the timescale of collective settling from Jacobs et al. (2015) to derive an equation for $h_{\text {crit }}$ that includes the effects of viscous and inertial drag on the settling velocities of individual particles as well as the effect of inertial drag on the plumes of particles. The timescales can be written as $\tau_{\text {ind }}=\frac{h}{u_{i}}$,

and

$\tau_{\text {coll }}=\sqrt{\frac{\rho_{f} h u_{i}}{\left(\rho_{p}-\rho_{f}\right) V_{p} g}}$.

As $\tau_{\text {coll }}=\tau_{\text {ind }}$ when $h=h_{\text {crit, }}$

$h_{\text {crit }}=\frac{4 \rho_{f} u_{i}^{3}}{\left(\rho_{p}-\rho_{f}\right) V_{p} g}$,

where $h$ is the thickness of the particle-rich layer and $u_{i}$ is the individual settling velocity of the particle (considering Re), $\rho_{f}$ is the fluid density, $\rho_{p}$ is the particle density, $g$ is gravitational acceleration and $V_{p}$ is the volumetric particle flux. The volumetric particle flux for each lake is calculated from

$V_{P}=\frac{M_{P}}{\rho_{\rho} A t_{e}}$,

where $M_{p}$ is the mass of tephra in the core, $A$ is the core area and $t_{e}$ the duration of the eruption (excluding repose intervals). We then calculated $h_{\text {crit }}$ as a function of particle size for each lake using Eq. (3) with $u_{i}$ calculated as per White (1974) as described above. This $h_{\text {crit }}$ calculation is a simplification as for
Fig. 8 Summary of the effect if particle size on $h_{\text {crit }}$ and on particle settling velocity. a The time for the range of particle sizes to settle via Stokes law settling through $18 \mathrm{~m}$ of water (depth of water for LQ03 core). The durations of the two sub-Plinian phases, as well as the repose time in between, are shown in dashed lines. b Grain size distribution for a core (binned at $1 \varphi$ intervals) from each of the three lakes. Black line indicates the particle size where water depth $>h_{\text {crit }}$ (assuming all particles the same size). c Values for $h_{\text {crit }}$ for the range of particle sizes in the cores. Dashed lines indicate the water depths at each coring location

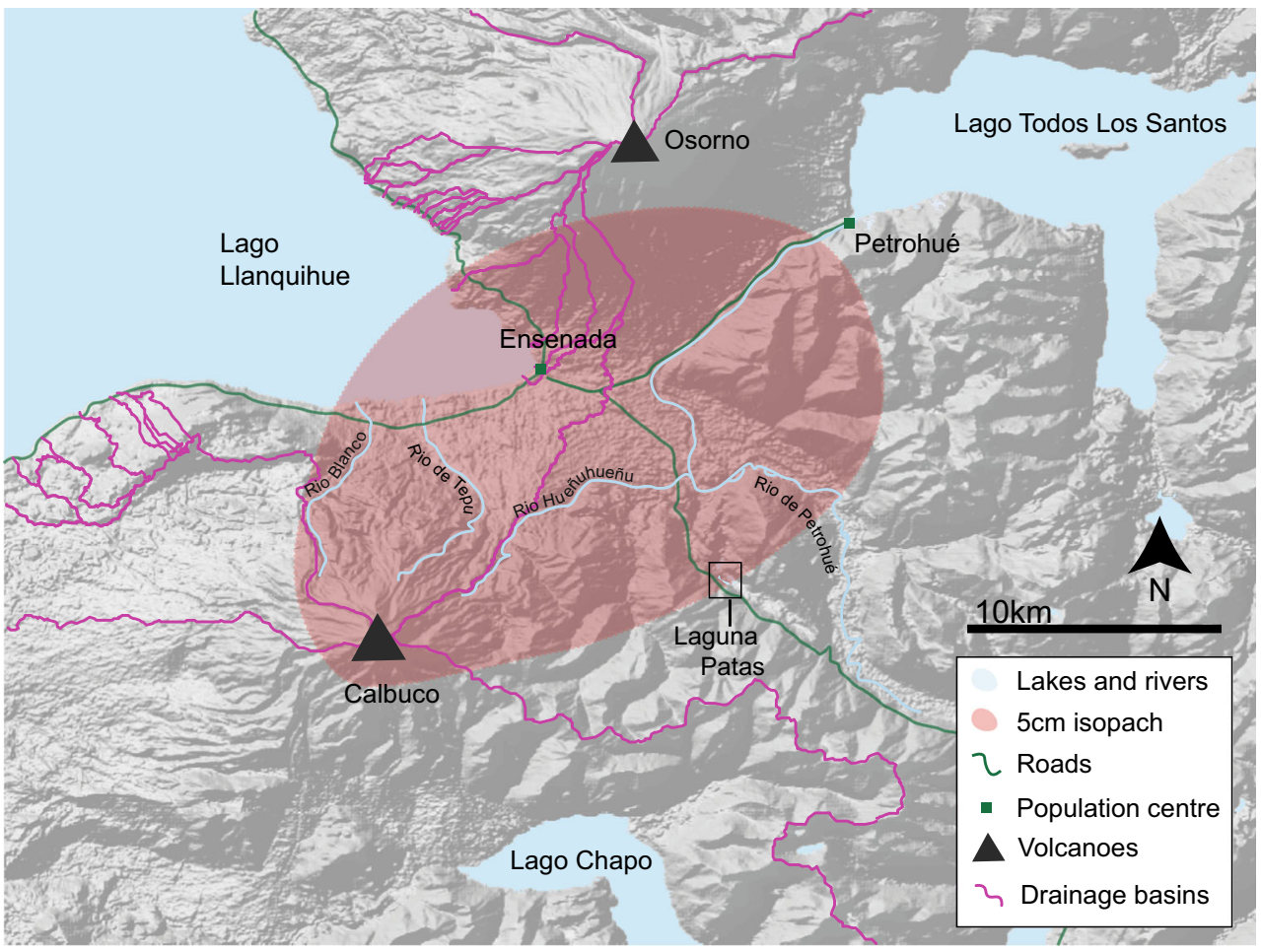


each particle size it is assumed that the entire mass of tephra $\left(M_{p}\right)$ is comprised of particles of that size. We conclude that the collective settling regime dominates only if most of the mass of the deposit comprises particles that are sufficiently small for a layer containing that grain size alone to have settled collectively.

In all three lakes, $h_{\text {crit }}$ is less than the lake depth for the smallest sampled particle sizes (Fig. 8b, c). In Todos Los Santos, which is the deepest lake and contains the finest deposit, our analysis indicates that collective settling would occur for most of the tephra in the deposit (Fig. 8b). In Laguna Patas and Lago Llanquihue, which are shallower and received coarser-grained tephra, only a small portion $(<20 \%)$ of the whole deposit mass would be sufficiently fine to settle collectively (Fig. 8b).

The calculated times for individual particles to fall through the entire water column (where we cored) are less than $5 \mathrm{~min}$, which is much shorter than the eruption duration $(1.5$ and $6 \mathrm{~h}$ for sub-Plinian phases 1 and 2, respectively). Therefore, individual particle settling should produce a lake floor stratigraphy that directly records the succession of material that landed on the lake as a function time, in the same way as the terrestrial stratigraphy. This explains why the deposits at Lago Llanquihue and Laguna Patas display similar stratigraphy to nearby sites on land.

The deposit in Todos Los Santos has a less clear stratigraphy with height than in the other lakes (Fig. 3), which may be a consequence of a more complicated settling regime. Our calculations imply that $\sim 80 \%$ of the mass of the deposit was sufficiently fine-grained for the particles to settle collectively if the whole mass of the deposit was composed of that size of particle (Fig. 8b). A collective settling regime may explain why the grain size of the whole deposit is consistent with land sections but the grain size changes with stratigraphic height in the deposit are less distinct. The timescales of settling also indicate that ash from the first eruptive phase would have been deposited as part of a density plume that was separate from that of the second eruptive phase, which occurred after a repose interval of $5.5 \mathrm{~h}$. The impact of successive plumes is hard to corroborate, however, as the range of grain sizes deposited becomes smaller with distance from the vent (Fig. 8b). Thus, any changes to the grain size with stratigraphic height will be small and may not be resolved by our grain size analyses.

\section{Conclusion}

We cored three lakes surrounding Calbuco volcano to sample the 2015 tephra deposit and compare it to nearby deposits. The lakes are of different types, sizes and location relative to the ash dispersal axis. We then examined the tephra in the lake in the context of the lake's catchment, the location of the cores relative to the fluvial network, the effect of lake sediment on the grain size distributions of the tephra and the particle settling regime.

Overall, we found that tephra deposited on the lake bed was an accurate representation of the terrestrial deposits. As the eruption had a distinct eruption sequence, it produced scoria of varying sizes, colour and density. The lake sediments displayed the same patterns in these three variables as the terrestrial sections.

The only exceptions were two cores sampled 300 and $160 \mathrm{~m}$ from the mouth of a river inflow in Laguna Patas. In these cases, the tephra in the core was poorly sorted and contained lenses of fine non-volcanic material. It was also considerably thicker than expected (when compared to the thickness of the nearest land sample) and thicker than predicted by the deposit isopachs, indicating an additional contribution of dominantly volcanic sediment from the river. The lack of correspondence in grain size and componentry with the nearby primary counterpart, even at the base of the deposit, indicates that river input of tephra started during the eruption.

Our results highlight that when choosing coring locations, the size, location and discharge rates of river, basins and lake catchments should be taken into consideration. Lakes fed from large catchment areas that directly underlie the ash plume are likely to be affected by secondary ash deposition. However, the discharge, size and catchment of the fluvial inflow all control fluvial inflows. For example, Lago Llanquihue is the second largest lake in Chile, yet only primary tephra deposition is recorded only a few kilometres from a river inflow fed from the flanks of the volcano. Smaller lakes are useful as they are typically subject to lower fluvial discharge rates and smaller catchments meaning any secondary deposition will have a small spatial extent. Additionally, they tend to be shallower and so easier to core with gravity corers at multiple intervals along the lake.

We also find that the particle settling regime is relevant to the stratigraphy of lacustrine tephra deposits. For the size, density and mass flux of particles landing at the locations, we cored; if the water had been $>40$ m deep, settling would have been as vertical density currents rather than as individual particles. Therefore, in contrast to deep-sea cores, there is the potential for settling in lakes to be as individual particles as we conclude was the case in the proximal lakes (Llanquihue and Laguna Patas). Importantly, the particles landing on these lakes were sufficiently large to settle to the lake floor in a time much shorter than the duration of the eruptive phases, explaining why the primary stratigraphy is preserved in the cored tephra. However, our calculation indicated that settling in the more distal Lago Todos Los Santos occurred (at least in part) as plumes of particles due to the finer grain size of the volcanic material, which may explain the homogenous median grain size with depth in the deposit.

We conclude that coring of lakes to gain primary volcanic records should generally avoid shallow, sediment-rich fluvial 
sediment fans at river mouths, and cores close to river inflows should be treated with care (or ideally not used). In addition, shallow water depths receiving coarser grain sizes are more likely to form deposits that preserve information on the temporal evolution of the eruption as the particles settled individually, not collectively as plumes.

Where the location relative to the river input is unknown (i.e. in paleolakes), or in a situation where lake core tephras provide the only opportunity for sampling, then the features of the deposit should be carefully examined. If the deposit does not show any grading and is a poorly sorted mixture of volcanic material, then thickness and grain size information should be treated with caution.

Acknowledgments We would like to thank Leonora Jarpa and Javier Cerda for their invaluable help in the field and with sampling the cores.

Funding information The work was funded by the Natural Environment Research Council RiftVolc grant NE/L013932/1 (to KM as part of studentship ref. 1868693) and the AXA Research Fund and a Royal Society Wolfson Merit Award (to KVC). AC acknowledges FONDAP project 15090013 .

Open Access This article is distributed under the terms of the Creative Commons Attribution 4.0 International License (http:// creativecommons.org/licenses/by/4.0/), which permits unrestricted use, distribution, and reproduction in any medium, provided you give appropriate credit to the original author(s) and the source, provide a link to the Creative Commons license, and indicate if changes were made.

\section{References}

Arismendi I, Sanzana J, Soto D (2011) Seasonal age distributions and maturity stage in a naturalized rainbow trout (Oncorhynchus mykiss Walbaum) population in southern Chile reveal an ad-fluvial life history. Ann Limnol Int J Limnol 47(2):133-140. https://doi.org/ 10.1051/limn/2011012

Benett KD (1986) Coherent slumping of early postglacial lake sediments at Hall Lake, Ontario, Canada. Boreas. Blackwell Publishing Ltd 15(3):209-215. https://doi.org/10.1111/j.1502-3885.1986.tb00923.x

Bertrand S, Daga R, Bedert R, Fontijn K (2014) Deposition of the 20112012 Cordón Caulle tephra (Chile, $\left.40^{\circ} \mathrm{S}\right)$ in lake sediments: implications for tephrochronology and volcanology. J Geophys Res Earth Surf 119:2555-2573. https://doi.org/10.1002/2014JF003321.Received

Bonadonna $\mathrm{C}$ et al (2005) Probabilistic modeling of tephra dispersal: Hazard assessment of a multiphase rhyolitic eruption at Tarawera, New Zealand. J Geophys Res B: Solid Earth 110(3):1-21. https:// doi.org/10.1029/2003JB002896

Bretón BP et al (2006) Bases Técnicas y Ambientales para la Elaboración de un Plan de Manejo y Reglamentación de la Pesca Recreativa en el Río Petrohué y sus Afluentes. Proyecto FIP N ${ }^{\mathrm{o}} 2004-32$

Burden RE, Phillips JC, Hincks TK (2011) Estimating volcanic plume heights from depositional clast size. J Geophys Res: Solid Earth 116(11):1-13. https://doi.org/10.1029/2011JB008548

Campos H (1986) Productividad ictica de rios y lagos Araucanos, Taller Internacional sobre ecologia y manejo de peces en lagos y embalses

Campos H et al (1988) Limnological study of Lake Llanquihue (Chile), morphometry, physics, chemistry, plankton and primary productivity. Arch Hydrobiol Suppl 81:37-67
Carazzo G, Jellinek M a (2012) A new view of the dynamics, stability and longevity of volcanic clouds. Earth Planet Sci Lett 325-326:39-51. https://doi.org/10.1016/j.epsl.2012.01.025

Carey S (1997) Influence of convective sedimentation on the formation of widespread tephra fall layers in the deep sea. Geology 25(9):839-842. https://doi.org/10.1130/0091-7613(1997)025<0839:IOCSOT>2.3.CO

Carey SN, Schneider J-L (2011) Volcaniclastic processes and deposits in the deep-sea. Dev Sedimentol. Elsevier 63:457-515. https://doi.org/ 10.1016/B978-0-444-53000-4.00007-X

Cashman KV, Fiske RS (1991) Fallout of pyroclastic debris from submarine volcanic eruptions. Science 253(5017):275-280. https://doi. org/10.1126/science. 253.5017 .275

Castruccio A, Clavero J (2015) Lahar simulation at active volcanoes of the southern Andes: implications for hazard assessment. Nat Hazards 77(2):693-716. https://doi.org/10.1007/s11069-015-1617-x

Castruccio A et al (2016) Eruptive parameters and dynamics of the April 2015 sub-Plinian eruptions of Calbuco volcano (southern Chile). Bull Volcanol 78(9). https://doi.org/10.1007/s00445-016-1058-8

Davis JO (1985) Correlation of Late Quaternary tephra layers in a long pluvial sequence near Summer Lake, Oregon. Quat Re. Cambridge University Press 23(1):38-53. https://doi.org/10.1016/00335894(85)90070-5

Engwell SL, Sparks RSJ, Carey S (2014) Physical characteristics of tephra layers in the deep sea realm: the Campanian Ignimbrite eruption. Marine Tephrochronol 398:47-64. https://doi.org/10.1144/SP398.7

Fierstein J, Nathenson M (1992) Another look at the calculation of fallout tephra volumes. Bull Volcanol 54(2):156-167. https://doi.org/10. 1007/BF00278005

Fiske RS, Naka J, Iizasa K, Yuasa M, Klaus A (2001) Submarine silicic caldera at the front of the Izu-Bonin arc, Japan: voluminous seafloor eruptions of rhyolite pumice. Geol Soc Am Bull 113(7):813-824

Fontijn K, Lachowycz SM, Rawson H, Pyle DM, Mather TA, Naranjo JA, Moreno-Roa H (2014) Late Quaternary tephrostratigraphy of southern Chile and Argentina. Quat Sci Rev. Elsevier Ltd 89:70 84. https://doi.org/10.1016/j.quascirev.2014.02.007

Fontijn K, Rawson H, van Daele M, Moernaut J, Abarzúa AM, Heirman K, Bertrand S, Pyle DM, Mather TA, de Batist M, Naranjo JA, Moreno H (2016) Synchronisation of sedimentary records using tephra: a postglacial tephrochronological model for the Chilean Lake District. Quat Sci Rev. Pergamon 137:234-254. https://doi. org/10.1016/J.QUASCIREV.2016.02.015

Geller W (1992) The temperature stratification and related characteristics of Chilean lakes in midsummer. Aquat Sci 54(1):37-57. https://doi. org/10.1007/BF00877263

Herschy RW (2012) World Lake Database: International Lake Environment Committee Foundation (ILEC). In: Herschy RW, Bengtsson L, Fairbridge RW (eds) Encyclopedia of lakes and reservoirs. Springer Netherlands, Dordrecht, pp 920-921. https://doi.org/ 10.1007/978-1-4020-4410-6 188

Horrocks M, Augustinus P, Deng Y, Shane P, Andersson S (2005) Holocene vegetation, environment, and tephra recorded from Lake Pupuke, Auckland, New Zealand. N Z J Geol Geophys. Taylor \& Francis 48(1):85-94. https://doi.org/10.1080/00288306.2005.9515100

Inman DL (1952) Measures for describing the size distribution of sediments. J Sediment Res 22(3):125-145. https://doi.org/10.1306/ D42694DB-2B26-11D7-8648000102C1865D

Jacobs CT, Collins GS, Piggott MD, Kramer SC, Wilson CRG (2013) Multiphase flow modelling of volcanic ash particle settling in water using adaptive unstructured meshes. Geophys J Int 192(2):647-665. https://doi.org/10.1093/gji/ggs059

Jacobs CT et al (2015) An improved quantitative measure of the tendency for volcanic ash plumes to form in water: Implications for the deposition of marine ash beds. J Volcanol Geotherm Res. Elsevier B.V. 290:114-124. https://doi.org/10.1016/j.jvolgeores.2014.10.015

Johnston EN, Phillips JC, Bonadonna C, Watson IM (2012) Reconstructing the tephra dispersal pattern from the Bronze Age eruption of Santorini 
using an advection-diffusion model. Bull Volcanol 74(6):1485-1507. https://doi.org/10.1007/s00445-012-0609-x

Lane CS, Chorn BT, Johnson TC (2013) Ash from the Toba supereruption in Lake Malawi shows no volcanic winter in East Africa at $75 \mathrm{ka}$. Proc Natl Acad Sci 110(20):8025-8029 Available at: http://www. pnas.org/content/110/20/8025.abstract. Accessed June 2018

Ledbetter MT, Sparks RSJ (1979) Duration of large-magnitude explosive eruptions deduced from graded bedding in deep-sea ash layers. Geology 7(5):240-244. https://doi.org/10.1130/0091-7613(1979) 7\%3C240:DOLEED\%3E2.0.CO

Legros F (2000) Minimum volume of a tephra fallout deposit estimated from a single isopach. J Volcanol Geotherm Res 96(1):25-32. https://doi.org/10.1016/S0377-0273(99)00135-3

Lopez-Escobar L et al (1992) A contribution to the petrogenesis of Osorno and Calbuco volcanoes, southern Andes (41 176' S): comparative study. Rev Geol Chile 19:211-226

Lowe DJ (2011) Quaternary Geochronology Tephrochronology and its application: a review. Quat Geochronol. Elsevier B.V 6(2):107-153. https://doi.org/10.1016/j.quageo.2010.08.003

Lowe DJ, Shane PAR, Alloway BV, Newnham RM (2008) Fingerprints and age models for widespread New Zealand tephra marker beds erupted since 30,000 years ago: a framework for NZ-INTIMATE. Quat Sci Rev. Pergamon 27(1-2):95-126. https://doi.org/10.1016/J. QUASCIREV.2007.01.013

Manville V, Wilson CJN (2004) Vertical density currents: a review of their potential role in the deposition and interpretation of deep-sea ash layers. J Geol Soc 161:947-958. https://doi.org/10.1144/0016764903-067

Marsh BD (1988) Crystal capture, sorting, and retention in convecting magma. Bull Geol Soc Am 100(11):1720-1737. https://doi.org/10. 1130/0016-7606(1988)100<1720:CCSARI >2.3.CO;2

Matthews NE, Smith VC, Costa A, Durant AJ, Pyle DM, Pearce NJG (2012) Ultra-distal tephra deposits from super-eruptions: examples from Toba, Indonesia and Taupo volcanic zone, New Zealand. Quat Int. Pergamon 258:54-79. https://doi.org/10.1016/J.QUAINT.2011.07.010

McNamara K et al (2018) Using lake sediment cores to improve records of volcanism at aluto volcano in the Main Ethiopian Rift. Geochem Geophys Geosyst in press. https://doi.org/10.1029/2018GC007686

Moreno PI, Alloway BV, Villarosa G, Outes V, Henríquez WI, de PolHolz R, Pearce NJG (2015) A past-millennium maximum in postglacial activity from Volcán Chaitén, southern Chile. Geology 43(1): 47-50. https://doi.org/10.1130/G36248.1

Ninkovich D, Shackleton NJ (1975) Distribution, stratigraphic position and age of ash layer "L", in the Panama Basin region. Earth Planet Sci Lett. Elsevier 27(1):20-34. https://doi.org/10.1016/0012821X(75)90156-9

Pyle DM (1989) The thickness, volume and grainsize of tephra fall deposits. Bull Volcanol 51(1):1-15. https://doi.org/10.1007/ BF01086757

Rhoades DA, Dowrick DJ, Wilson CJN (2002) Volcanic hazard in New Zealand: scaling and attenuation relations for tephra fall deposits from Taupo volcano. Nat Hazards 26(2):147-174. https://doi.org/ 10.1023/A: 1015608732356

Riggs NR et al (2001) Post-1.8-ka marginal sedimentation in Lake Taupo, New Zealand: effects of wave energy and sediment supply in a rapidly rising lake. In: White, J.D.L., Riggs, N.R. (Eds.), Volcaniclastic Sedimentation in Lacustrine Settings. IAS Spec. Publ. 30. Blackwell Scientific Publications, Oxford, pp. 151-177.

Romero JE et al (2016) Eruption dynamics of the 22-23 April 2015 Calbuco volcano (southern Chile): analyses of tephra fall deposits. J Volcanol Geotherm Res. Elsevier B.V. 317:15-29. https://doi.org/ 10.1016/j.jvolgeores.2016.02.027

Rose WI, Durant AJ (2009) Fine ash content of explosive eruptions. J Volcanol Geotherm Res 186(1-2):32-39. https://doi.org/10.1016/j. jvolgeores.2009.01.010
Schindelin J, Arganda-Carreras I, Frise E, Kaynig V, Longair M, Pietzsch T, Preibisch S, Rueden C, Saalfeld S, Schmid B, Tinevez JY, White DJ, Hartenstein V, Eliceiri K, Tomancak P, Cardona A (2012) Fiji: an open-source platform for biological-image analysis. Nat Methods 9(7):676-682. https://doi.org/10.1038/nmeth.2019

Segura A et al (2015) Fallout deposits of the 22-23 April 2015 eruption of Calbuco volcano, southern Andes. Impact Geosci Soc 182-184

Selles D, Moreno H (2011) Geología del volcán Calbuco, Región de los Lagos. Servicio Nacional de Geología y Minería. Carta Geol Chile

Shane P, Black T, Eggins S, Westgate J (1998) Late Miocene marine tephra beds: recorders of rhyolitic volcanism in North Island, New Zealand. N Z J Geol Geophys. Taylor \& Francis 41(2):165-178. https://doi.org/10.1080/00288306.1998.9514801

Shane P, Sikes EL, Guilderson TP (2006) Tephra beds in deep-sea cores off northern New Zealand: implications for the history of Taupo volcanic zone, Mayor Island and White Island volcanoes. J Volcanol Geotherm Res 154(3):276-290. https://doi.org/10.1016/j. jvolgeores.2006.03.021

Smith VC, Staff RA, Blockley SPE, Bronk Ramsey C, Nakagawa T, Mark DF, Takemura K, Danhara T (2013) Identification and correlation of visible tephras in the Lake Suigetsu SG06 sedimentary archive, Japan: chronostratigraphic markers for synchronising of east Asian/west Pacific palaeoclimatic records across the last 150 ka. Quat Sci Rev. Pergamon 67:121-137. https://doi.org/10.1016/J. QUASCIREV.2013.01.026

Soto D (2002) Patrones oligotróficos en lagos del sur de Chile: relevancia de los nutrientes y de la profundidad de mezcla. Rev Chil Hist Nat 75(May):377-393

Stern CR (2008) Holocene tephrochronology record of large explosive eruptions in the southernmost Patagonian Andes. Bull Volcanol 70(4):435-454. https://doi.org/10.1007/s00445-007-0148-z

Thompson R, Bradshaw RHW, Whitley JE (1986) The distribution of ash in Icelandic lake sediments and the relative importance of mixing and erosion processes. J Quat Sci. John Wiley \& Sons, Ltd 1(1):311. https://doi.org/10.1002/jqs.3390010102

Van Daele M et al (2014) The 600 yr eruptive history of Villarrica volcano (Chile) revealed by annually laminated lake sediments. GSA Bull 126(3-4):481-498. https://doi.org/10.1130/B30798.1

Van Daele M et al (2015) A comparison of the sedimentary records of the 1960 and 2010 great Chilean earthquakes in 17 lakes: implications for quantitative lacustrine palaeoseismology. Sedimentology 62: 1466-1496. https://doi.org/10.1111/sed.12193

Van Eaton AR et al (2016) Volcanic lightning and plume behavior reveal evolving hazards during the April 2015 eruption of Calbuco volcano, Chile. Geophys Res Lett 43(7):3563-3571. https://doi.org/10. 1002/2016GL068076

Von Lichtan IJ et al (2016) Giant rafted pumice blocks from the most recent eruption of Taupo volcano, New Zealand: insights from palaeomagnetic and textural data. J Volcanol Geotherm Res. Elsevier 318:73-88. https://doi.org/10.1016/J.JVOLGEORES. 2016.04.003

White FM (1974) Viscous fluid flow. McGraw-Hill, New York

White JDL et al (2009) Settling and deposition of AD 181 Taupo pumice in lacustrine and associated environments. In: White JDL and Riggs NR (eds) Volcaniclastic Sedimentation in Lacustrine Settings, vol 1, p 141-150. https://doi.org/10.1002/9781444304251

Whitham AG, Sparks RSJ (1986) Pumice. Bull Volcanol 48:209-223. https://doi.org/10.1007/BF01087675

Wiesner MG, Wang YB, Zheng LF (1995) Fallout of volcanic ash to the deep South China Sea induced by the 1991 eruption of Mount Pinatubo (Philippines). Geology 23(10):885-888. https://doi.org/ 10.1130/0091-7613(1995)023

Williams DF et al (1997) Lake Baikal record of continental climate response to orbital insolation during the past 5 million years. Science 278(5340):1114-1117 Available at: http://science.sciencemag.org/ content/278/5340/1114.abstract. Accessed June 2018 